\title{
Glial Growth Factor 2, a Soluble Neuregulin, Directly Increases Schwann Cell Motility and Indirectly Promotes Neurite Outgrowth
}

\author{
Nagesh K. Mahanthappa, ${ }^{1}$ Eva S. Anton, ${ }^{2}$ and William D. Matthew ${ }^{2}$ \\ ${ }^{1}$ Cambridge NeuroScience, Inc., Cambridge, Massachusetts 02139, and 2Department of Neurobiology, Duke University \\ Medical Center, Durham, North Carolina 27710
}

\begin{abstract}
Schwann cells proliferate, migrate, and act as sources of neurotrophic support during development and regeneration of peripheral nerves. Recent studies have demonstrated that neuregulins, a family of growth factors secreted by developing motor and peripheral neurons, influence Schwann cell development. In this study, we use three distinct assays to show that glial growth factor 2 (GGF2), a secreted neuregulin, exerts multiple effects on mature Schwann cells in vitro. At doses submaximal for proliferation, GGF2 increases the motility of Schwann cells cultured on peripheral nerve cryosections. Furthermore, in a novel bioassay, focal application of GGF2 causes directed migration in conventional monolayer cultures of
\end{abstract}

Glial growth factor (GGF) was originally characterized as a single Schwann cell mitogen (Lemke and Brockes, 1984). Purification showed that GGFs are a group of proteins encoded by differentially spliced transcripts of a single gene (Goodearl et al., 1993; Marchionni et al., 1993). The same gene encodes ARIA (Falls et al., 1993) and ligands of erbB2 (Holmes et al., 1992; Wen et al., 1992). These proteins are known collectively as neuregulins and are thought to act through heterodimers of erbB2, erbB3, and erbB4 (for review, see Carraway and Burden, 1995). In primary cultures of Schwann cells, recombinant human GGF2 (rhGGF2), a secreted neuregulin, causes phosphorylation of erbB2 and erbB3 and subsequent proliferation (Marchionni et al., 1993; Sudhalter et al., 1996).

In situ hybridization studies show that neuregulin mRNAs are expressed from midgestation onward in dorsal root ganglion (DRG) and in motor and sympathetic ganglion neurons (Marchionni et al., 1993; Orr-Urtreger et al., 1993; Chen et al., 1994; Meyer and Birchmeier, 1994). In clonally derived neural crest cell cultures, neuregulins bias cell lineage toward Schwann cells while inhibiting the production of neurons (Shah et al., 1994). Neuregulins are trophic for the Schwann cell precursors and at higher concentrations drive proliferation and maturation (Dong et al., 1995). In the developing neuromuscular junction, neuregulins are also critical for the survival of terminal Schwann cells (Trachtenberg and Thompson, 1996). Together with the localization data,

\footnotetext{
Received March 26, 1996; revised May 7, 1996; accepted May 9, 1996.

W.D.M. thanks Cambridge NeuroScience, Inc., for funding portions of this study that were completed in his laboratory. We thank C. Kirk and W. Holt for encouraging this work; J. Sudhalter, K. Cronin, E. Happel, and D. Jones for technical support; M. Pita for excellent graphics assistance; and M. Marchionni, R. McBurney,

$\mathrm{T}$. Ingolia, and S. Scherer for critically reading this manuscript.

Correspondence should be sent to Dr. Nagesh K. Mahanthappa at his present address: Ontogeny, Inc., 45 Moulton Street, Cambridge, MA 02138.

Dr. Anton's present address: Section of Neurobiology, Yale University School of Medicine, New Haven, CT 06510.

Copyright (C) 1996 Society for Neuroscience $0270-6474 / 96 / 164673-11 \$ 05.00 / 0$
}

Schwann cells. At higher doses, GGF2 causes proliferation, as described previously. In a new explant culture system designed to emulate entubulation repair of transected peripheral nerves, GGF2 concentrations greater than necessary to saturate the mitotic response induce the secretion by Schwann cells of activities that promote sympathetic neuron survival and outgrowth. These findings support a model in which neuregulins secreted by peripheral neurons are key components of reciprocal neuron-glia interactions that are important for peripheral nerve development and regeneration.

Key words: Schwann cell; nerve regeneration; neuregulin; glial growth factor; migration; neurotrophic activity these studies support a model in which neuregulin expression by developing peripheral neurons suppresses overproduction of new neurons while supporting Schwann cell development. Targeted deletion of the genes encoding neuregulins, erbB2, and erbB4 vindicate such a model because the resulting mice display severe defects in Schwann cell production and in the formation of sensory and motor nerves (Gassmann et al., 1995; Lee et al., 1995; Meyer and Birchmeier, 1995). The continued expression of neuregulins in adults, however, suggests an additional role in peripheral nerve maintenance and/or regeneration (Chen et al., 1994).

In this report, we provide evidence that postnatal Schwann cells exhibit multiple responses to rhGGF2 that are separable temporally and by dose. Using a system in which DRG explants are cultured on cryosections of peripheral nerve, we show that low concentrations of rhGGF2 increase Schwann cell migration without significant proliferation. By applying rhGGF2 focally in cultures of pure Schwann cells, we show that this migration is chemotactic and precedes proliferation. Although increasing doses of rhGGF2 promote Schwann cell division, higher doses promote Schwann cell secretion of neural growth-promoting activities in a novel, superior cervical ganglion (SCG) explant culture system. These findings support a model in which regenerating peripheral neurons, by expressing neuregulins, can (1) recruit Schwann cells (chemotaxis), (2) cause proliferation of these cells, and (3) induce local production of needed trophic support. Thus neuregulins may function as a critical element in a reciprocating growth factor circuit that allows neurons and glia to cooperatively promote nerve development and regeneration.

\section{MATERIALS AND METHODS}

Schwann cell migration and proliferation on sciatic nerve cryosections. Cervical or thoracic level DRGs were removed from 1-d-old SpragueDawley rat pups (Charles River, Wilmington, MA) and placed in ice-cold RPMI medium (Life Technologies, Grand Island, NY) containing 10\% fetal bovine serum (FBS) (Hyclone, Logan, UT). To remove the capsules, 
the DRGs were first incubated in RPMI medium containing $0.25 \%$ trypsin (Sigma, St. Louis, MO) and $0.03 \%$ collagenase (Sigma) for 30 min, and then with $0.01 \%$ DNase (Sigma) and $0.25 \%$ anti-trypsin (Sigma) in RPMI $/ 10 \%$ FBS medium for $15 \mathrm{~min}$ at $37^{\circ} \mathrm{C}$. The DRGs were then rinsed once in RPMI/10\% FBS medium, cleaned of the digested capsule, and explanted onto $22-\mu \mathrm{m}$-thick, longitudinal cryostat sections of adult sciatic nerves. BSA or rhGGF2 was added to the culture medium at the indicated concentrations. After $72 \mathrm{hr}$, cultures were incubated in $10 \mathrm{~mm}$ 5(6)-carboxyfluorescein diacetate succinimidyl ester (Molecular Probes, Eugene, OR) for $5 \mathrm{~min}$ and examined immediately using a Zeiss fluorescence microscope. Images of these cultures were collected on an optical disk, and the Image-1 program (Universal Imaging, Media, PA) was used to measure the extent of Schwann cell migration, as described previously (Anton et al., 1994). The statistical significance of differences between experimental groups was tested by Student's $t$ test.

The mitotic status of the migrating Schwann cells was determined by supplementing the growth medium of the cultures with $10 \mu \mathrm{M}$ 5-bromo2'-deoxyuridine (BrdU) (Boehringer Mannheim, Indianapolis, IN) at 48 $\mathrm{hr}$. After $72 \mathrm{hr}$ of incubation, cultures were processed by indirect immunofluorescence labeling for $\mathrm{BrdU}$ incorporation (1:100 fluoresceinconjugated anti-BrdU antibody; Boehringer Mannheim), nuclei were counterstained with $10 \mu \mathrm{M}$ bis-benzamide (Sigma), and mitotic profiles of the migrating Schwann cells were analyzed.

Purified Schwann cell culture. Schwann cells were prepared from the sciatic nerves of 3-d-old rats by the methods of Brockes (1987). Cells were plated in low glucose DME (Fisher/Mediatech, Pittsburgh, PA) supplemented with $10 \%$ heat-inactivated FBS (HI-FBS, Hyclone) and maintained at $37^{\circ} \mathrm{C}$ in a $10 \% \mathrm{CO}_{2}$ tissue culture incubator. Serum batches were prescreened for a lack of Schwann cell proliferation activity under these conditions. Fibroblasts were eliminated by initially culturing the cells in the presence of $10 \mu \mathrm{M}$ cytosine arabinoside and subsequently using complement-mediated lysis directed against the fibroblast antigen Thy-1. The latter step used the monoclonal antibody T11D7e (Serotec USA, Washington, DC) and rabbit complement (Life Technologies). On further expansion in rhGGF2, cells stocks were frozen for future use or rendered quiescent by culture in low-glucose DME (Fisher/Mediatech) supplemented with 5\% HI-FBS in the absence of rhGGF2 for a minimum of $3 \mathrm{~d}$ before use. Cells were never used beyond three passages. Purified rhGGF2 was prepared as described previously (Rutkowski et al., 1995). If cultures were to be labeled with $\mathrm{BrdU}$, the compound was added to a concentration of $10 \mu \mathrm{M}$ for the duration of the specified labeling period.

$S C G$ neuron culture. SCGs were dissected from postnatal day $0-1$ rats. Ganglia were cleaned of nerve stumps and any associated connective tissue, fat, etc., and bisected. When being used in "tube cultures" (see below), the tissue was held in Lebovitz's L-15 medium on ice until needed. For the production of pure neuron cultures, connective tissue sheaths and nerve stumps were cut away under the dissecting microscope, and the ganglia were enzymatically dissociated for $30 \mathrm{~min}$ at $37^{\circ} \mathrm{C}$ using $1 \mathrm{mg} / \mathrm{ml}$ collagenase A (Boehringer Mannheim) and $1 \mathrm{mg} / \mathrm{ml}$ trypsin (Sigma) in $\mathrm{Ca} / \mathrm{Mg}$-free HBSS (Life Technologies). After trituration with a flame-polished Pasteur pipette to yield single cells, the suspension was pelleted, resuspended in low-glucose DME supplemented with 5\% HIFBS, and allowed to preplate for $1-2 \mathrm{hr}$ under the same conditions as those in which the Schwann cells were cultured (preplating removes most remaining fibroblasts and macrophages). Cells were finally plated in the indicated media, with or without recombinant human nerve growth factor (rhNGF) (Boehringer Mannheim), in 24-well plates $\left(5 \times 10^{3}\right.$ cells/well) precoated with type I collagen (Fisher/Collaborative Research, Pittsburgh, PA).

Coated bead preparation. Heparin-Sepharose beads were obtained by opening a $5 \mathrm{ml}$ HiTrap Heparin column (Pharmacia, Piscataway, NJ). These beads range in size from 24 to $44 \mu \mathrm{m}$ and contain a six-atom spacer between the bead matrix and the heparin moieties. The beads were washed three times with an equal volume of PBS and were then made into a $50 \% \mathrm{v} / \mathrm{v}$ slurry in PBS with $1 \mathrm{mg} / \mathrm{ml}$ BSA (PBS/BSA). This slurry was allowed to incubate at $37^{\circ} \mathrm{C}$ with end-over-end rotation for $1 \mathrm{hr}$ to block nonspecific protein binding sites and then was stored at $4^{\circ} \mathrm{C}$ for future use. To coat beads with rhGGF2, aliquots of the slurry were incubated in various concentrations of rhGGF2 diluted in PBS/BSA for $1 \mathrm{hr}$ at $37^{\circ} \mathrm{C}$ with end-over-end rotation. These incubations were performed in microcentrifuge tubes, and the beads were washed three times by centrifugation and resuspension in Schwann cell medium. Final suspensions were stored at $4^{\circ} \mathrm{C}$ until needed. Bead concentrations were determined by counting with a hemocytometer. The amount of rhGGF2 bound to the beads was determined by pelleting a defined volume of beads, resuspend- ing them in $1 \mathrm{M} \mathrm{NaCl}$, and incubating for $1 \mathrm{hr}$ at $37^{\circ} \mathrm{C}$ with end-over-end rotation. Beads were removed by centrifugation, and the amount of rhGGF2 eluted from the beads was quantified by ELISA using affinitypurified rabbit polyclonal antibodies directed to rhGGF2.

Tube culture preparation. Tube cultures were established in Intramedic polyethylene tubing with an inner diameter of $1.19 \mathrm{~mm}$ (Baxter, Bedford, MA) that was sterilized by immersion and rinsing with $70 \% \mathrm{EtOH}$, air-dried in a tissue culture hood, and cut to $10 \mathrm{~mm}$ lengths using a sterile scalpel. To fill the tubing with low glucose DME supplemented with 5\% HI-FBS and $1.5 \mathrm{mg} / \mathrm{ml}$ type I collagen, the following components were mixed and kept on ice or at $4^{\circ} \mathrm{C}$ until they were used: $1.5 \mathrm{ml}$ of $37 \mathrm{mg} / \mathrm{ml}$ sodium bicarbonate, $0.15 \mathrm{ml}$ of penicillin/streptomycin $(10 \mathrm{kU} / \mathrm{ml}$ and 10 $\mathrm{mg} / \mathrm{ml}$, respectively) solution (Sigma), $0.15 \mathrm{ml}$ of $200 \mathrm{~mm}$ glutamine (Sigma), $0.75 \mathrm{ml}$ of HI-FBS, $1.5 \mathrm{ml}$ of $10 \times$ DME (powder from Sigma mixed to this concentration), $2.6 \mathrm{ml}$ of tissue culture grade water (Sigma), $0.9 \mathrm{ml}$ of $0.1 \mathrm{M} \mathrm{NaOH}$, and $7.4 \mathrm{ml}$ of $3 \mathrm{mg} / \mathrm{ml}$ type I bovine collagen (Vitrogen) (Celtrix, Santa Clara, CA). The final solution was dispensed into smaller aliquots to which rhGGF2 or other factors could be added to the indicated concentrations.

To assemble the tube cultures, all materials were cooled to $4^{\circ} \mathrm{C}$, and a dissecting microscope was placed in a $4^{\circ} \mathrm{C}$ room. Under the microscope, individual segments of tubing were filled with the collagen-containing medium using a $1 \mathrm{ml}$ syringe with a 28 gauge hypodermic needle (total culture volume $=\sim 12 \mu \mathrm{l}$ ). Half of an SCG was then placed in one end of the segment. Barely touching the tissue to the meniscus of the medium caused the surface tension to pull the tissue into the tube and leave it at the extreme end of the tube. Each completed assembly was then placed in an individual well of a 24-well culture plate. The only liquid added to these plates was tissue culture grade water that filled all wells along the perimeter of the plate and the interwell spaces (thus only the eight central wells remained dry and contained single tubes). The plates were then sealed with paraffin film and placed in a $37^{\circ} \mathrm{C}$ tissue culture incubator. Within $1 \mathrm{hr}$, the medium gelled, and the tube cultures remained viable for up to $10 \mathrm{~d}$.

To pulse these cultures with BrdU, tubes were submerged overnight in $1 \mathrm{ml}$ of low glucose DME supplemented with 5\% HI-FBS, $10 \mu \mathrm{M} \mathrm{BrdU,}$ and a concentration of growth factor matching that of the tube culture. At the end of the pulse period, cultures were fixed (see below) or transferred to medium free of BrdU for an additional $48 \mathrm{hr}$ (the medium was changed after $24 \mathrm{hr}$ ) before being cultured "dry" again. Small molecules readily penetrate the collagen gel, and two changes of BrdU-deficient media result in a $>7000$-fold dilution of unincorporated BrdU.

Staining and counting. Neurons were marked by a monoclonal antibody directed against tubulin $\beta$ III (Sigma); Schwann cells were marked by rabbit polyclonal antibodies directed against S-100 (Incstar, Stillwater, $\mathrm{MN}$ ); BrdU incorporation was detected by staining with a monoclonal antibody directed against the nucleotide (Dako, Carpinteria, CA). For tubulin or S-100 staining, conventional cultures were fixed with $4 \%$ paraformaldehyde in PBS for $30 \mathrm{~min}$, washed three times with PBS, blocked with $2 \%$ normal goat serum and $0.1 \%$ Triton X-100 in PBS for 30 min, placed in primary antibody for $1 \mathrm{hr}$ (1:200, tubulin; 1:4, S-100; all diluted in blocking solution), rinsed three times with PBS, placed in secondary antibody for $1 \mathrm{hr}(1: 200-1: 500$, horse radish peroxidase or alkaline phosphatase conjugated goat anti-mouse, or goat anti-rabbit; diluted in blocking buffer), rinsed three times with PBS, and then reacted with DAB or AEC for peroxidase-coupled secondaries or NBT/BCIP for phosphatase-coupled secondaries. In the case of BrdU staining, after cultures were fixed with paraformaldehyde, they were fixed for an additional $20 \mathrm{~min}$ in $70 \% \mathrm{EtOH}$, washed three times with water, and incubated in $2 \mathrm{M} \mathrm{HCl}$ for $30 \mathrm{~min}$ at $37^{\circ} \mathrm{C}$, followed by aspiration and neutralization with $0.1 \mathrm{~m}$ borate buffer, $\mathrm{pH} 9.0$, and washing three times with PBS. All other steps were the same as above but were performed at $37^{\circ} \mathrm{C}$ up to the chromogen reaction. In the case of the tube cultures, the tube-containing wells were filled with PBS, and the cultures were extruded into the wells using a $1 \mathrm{ml}$ syringe. The collagen gel is fairly sturdy and can be stained as a "whole mount." Staining is as above, but the removal of all solutions during fixation, staining, and washing procedures was performed under a dissecting microscope using a hand-held syringe.

Counting of cells in conventional cultures was performed at a magnification of $100 \times$, with five fields scored per well and at least two wells set up per condition per experiment. For tube cultures, extruded and stained gels were mounted on microscope slides, and using a grid reticule at a magnification of $160 \times$, every feature of interest (e.g., Schwann cells, neurites) was scored by counting and noting the distance of the feature from the ganglion in grid units. Each grid unit was 
determined to be $50 \mu \mathrm{m}$ by using a stage micrometer. For each condition and time point, at least three tube cultures were scored. All data are presented as average \pm SEM.

\section{RESULTS}

\section{Multiple migration assays}

The results of three distinct assays in which Schwann cell motility can be observed are as follows. The first makes use of DRG explants cultured on cryosections of peripheral nerve. This assay provides Schwann cells with an optimal culture substrate and reveals quantitative changes in Schwann cell motility in response to soluble additives. The second assay makes use of rhGGF2coated beads seeded onto monolayer cultures of pure Schwann cells, and it can be used to make qualitative assessments of changes in directed motility in the absence of confounding stimuli from other cell types. The third assay uses SCG explants cultured within three-dimensional collagen gels, and it allows for longerterm cultures in which the behavior of both Schwann cells and axons can be examined with quantitative rigor. Each assay is different, but the results are complementary because the first demonstrates increased Schwann cell motility, the second demonstrates Schwann cell chemotaxis, and the third reveals the interplay between migrating Schwann cells and the axons that follow.

\section{rhGGF2 promotes Schwann cell migration on sciatic nerve cryosections}

Using previously established protocols (Anton et al., 1994), the extent of Schwann cell migration from neonatal DRG explants on cryosections of adult sciatic nerve substrates was studied in the absence or presence of rhGGF2 (Fig. $1 A, B$ ). When assessed after $3 \mathrm{~d}$ in culture, the maximum distance traveled by lead Schwann cells on sciatic nerve substrates was increased by $\sim 63 \%$ over controls at rhGGF2 concentrations of $\geq 2.5 \mathrm{ng} / \mathrm{ml}$ (Fig. 1C). The increased migration distance observed at $2.5 \mathrm{ng} / \mathrm{ml}$ is statistically significant over controls $(p<0.01)$, whereas there is no significant difference between the effects of 2.5 and $20 \mathrm{ng} / \mathrm{ml}$. Thus the effect of rhGGF2 on Schwann cell migration seems to saturate at a dose approximately one order of magnitude less than necessary to induce maximal Schwann cell proliferation (Table 1) (Rutkowski et al., 1995). To ensure that rhGGF2-enhanced Schwann cell migration in this assay occurs by a mechanism independent of mitotic expansion of the Schwann cell population, the mitotic status of the migrating Schwann cells was determined by supplementing the growth medium with $10 \mu \mathrm{M}$ BrdU after $48 \mathrm{hr}$ in culture. Because the major thrust of Schwann cell migration in this assay occurs between 48 and $72 \mathrm{hr}$ in vitro, we hypothesized that any influence of mitosis on Schwann cell migration is best detected during this time interval by a BrdU pulse. Staining for $\mathrm{BrdU}$ revealed only occasional incorporation into migrating Schwann cells, thus indicating that mitosis does not play a role in rhGGF2-enhanced cell migration at low doses (data not shown).

\section{Focal application of rhGGF2 sequentially causes chemotaxis and then proliferation of cultured Schwann cells}

Because rhGGF2 binds heparin with a dissociation constant of 5-10 nм (Sudhalter et al., 1996), heparin-Sepharose beads were coated in solutions of varying rhGGF2 concentrations to present the factor to pure Schwann cell cultures in a focal manner. The strength of rhGGF2/heparin binding is such that most of the growth factor is tethered to the beads, whereas a small amount continuously leaches off and creates highly localized and steep
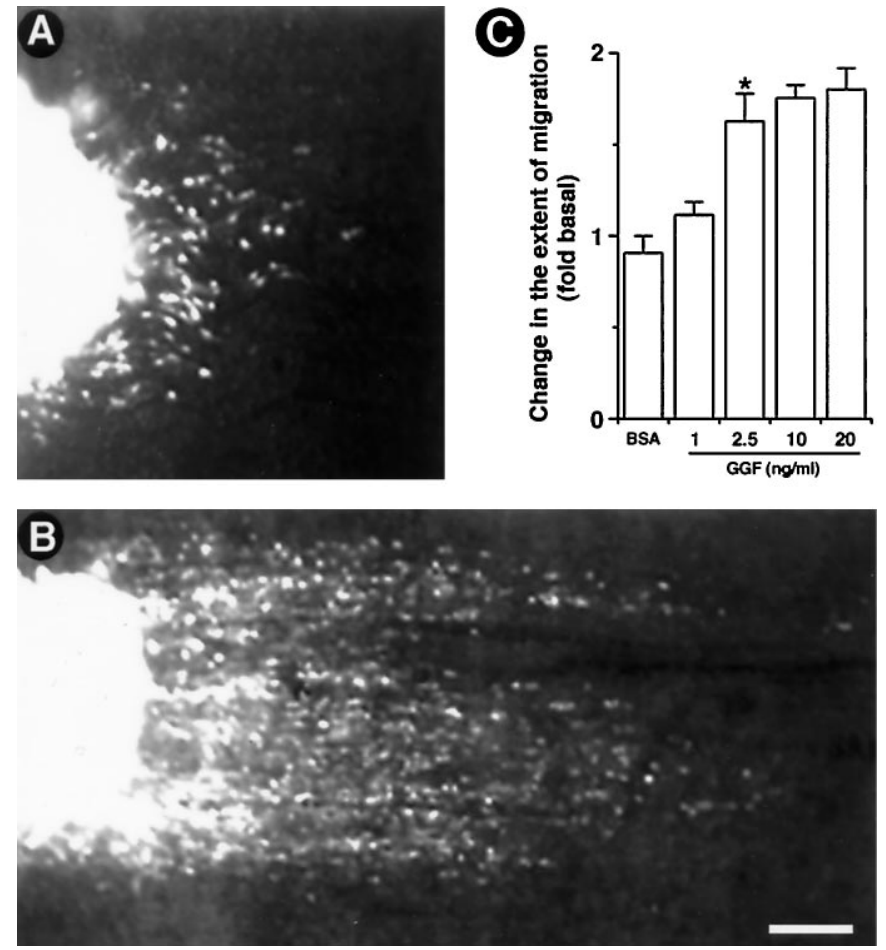

Figure 1. GGF2-induced enhancement of Schwann cell migration. The maximum extent of Schwann cell migration from neonatal DRG explants onto sciatic nerve sections was measured in the presence of different concentrations of GGF2. $A$, The extent of migration under control conditions (no additives). At an rhGGF2 concentration submaximal for proliferation, $2.5 \mathrm{ng} / \mathrm{ml}$, the extent of Schwann cell migration is enhanced by $\sim 63 \%(B)$. The maximum distance of Schwann cell migration under different conditions $(C)$ was plotted as fold increase from the basal level (no additives). Bars represent the average \pm SEM. BSA $(2.5 \mathrm{ng} / \mathrm{ml}), n=$ 5; rhGGF2 concentrations of $1 \mathrm{ng} / \mathrm{ml}, n=5 ; 2.5 \mathrm{ng} / \mathrm{ml}, n=13 ; 10 \mathrm{ng} / \mathrm{ml}$, $n=10$; and $20 \mathrm{ng} / \mathrm{ml}, n=7$. Asterisk designates difference from the BSA condition with $p<0.01$. Scale bar, $100 \mu \mathrm{m}$.

concentration gradients of soluble factor attributable to thermal mixing. As shown in Table 1, beads were coated with $0,0.75,1.5$, 3,6 , and $12 \mathrm{pg}$ rhGGF2/bead (corresponding to $0,6.2,12.5,25,50$, and $100 \%$ of binding capacity). To block nonspecific binding, rhGGF2 coating was performed in the presence of $1 \mathrm{mg} / \mathrm{ml} \mathrm{BSA}$ after the beads had been preincubated in $1 \mathrm{mg} / \mathrm{ml} \mathrm{BSA}$ alone (control beads are solely BSA-coated). The beads were administered to Schwann cell cultures maintained in 24-well tissue culture

Table 1. Quantification of rhGGF2 bound to heparin-Sepharose beads

\begin{tabular}{rlll}
$\begin{array}{l}\text { \% of } \\
\text { saturation }\end{array}$ & $\begin{array}{l}\text { Picograms of } \\
\text { rhGGF2 } \\
\text { per bead }( \pm 7 \%)\end{array}$ & $\begin{array}{l}\text { Eq of BrdU } \mathrm{Br}^{+} \\
\text {concentration }^{a}\end{array}$ & $\begin{array}{l}\text { cells in } \\
\text { equivalent } \\
\text { concentrations }^{b}\end{array}$ \\
\hline 6.2 & 0.75 & $1.1 \mathrm{ng} / \mathrm{ml}$ & $10.4 \pm 2.8$ \\
12.5 & 1.5 & $2.2 \mathrm{ng} / \mathrm{ml}$ & $25.3 \pm 5.6$ \\
25.0 & 3.0 & $4.5 \mathrm{ng} / \mathrm{ml}$ & $38.5 \pm 4.7$ \\
50.0 & 6.0 & $9.0 \mathrm{ng} / \mathrm{ml}$ & $53.5 \pm 3.2$ \\
100.0 & 12.0 & $18.0 \mathrm{ng} / \mathrm{ml}$ & $86.2 \pm 6.1$
\end{tabular}

Beads were coated to the indicated degrees of saturation and the amount of bound rhGGF2 immunoassayed (see Materials and Methods for details). Cultures in Figures 2 and 3 received 1500 beads $/ \mathrm{ml}$, and the equivalent concentration of free rhGGF2 was applied to the cells in Figure 4.

${ }^{a}$ Assumes 1500 beads fully released into $1 \mathrm{ml}$ of medium.

${ }^{b}$ Assessed at 40 hours, $n=5$ fields (corresponds to Fig. 4). 

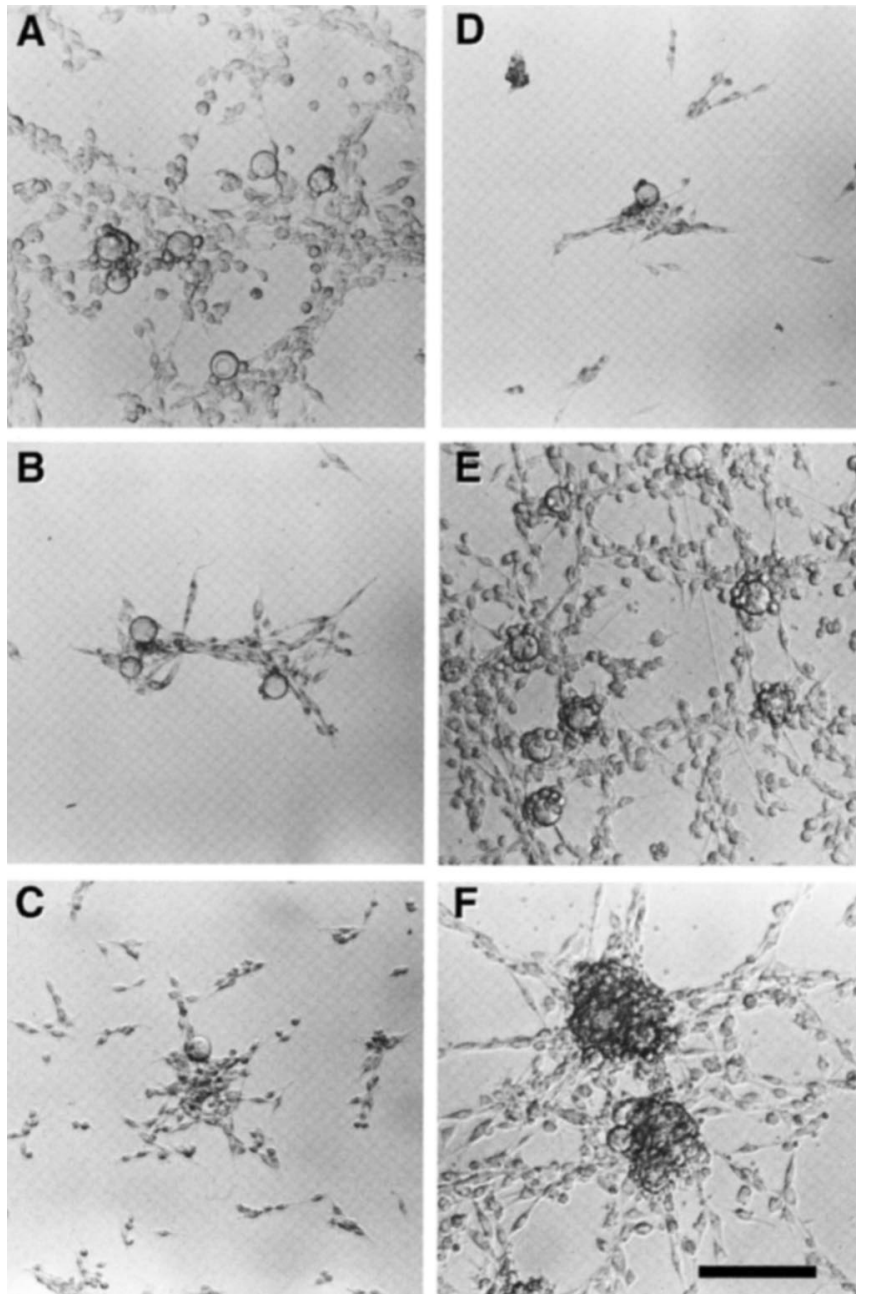

Figure 2. Beads coated with rhGGF2 promote Schwann cell chemotaxis. Heparin-Sepharose beads were coated with rhGGF2 to varying degrees of saturation (see Table 1) and were incubated with pure Schwann cell cultures for $15 \mathrm{hr}$. Cultures were stained for BrdU incorporation in parallel with those in Figures 3 and 4, and little staining was observed. Concentrations of rhGGF2 (pg/bead): $(A) 0,(B) 0.75,(C) 1.5,(D) 3.0,(E)$ 6.0 , and $(F)$ 12.0. Scale bar, $130 \mu \mathrm{m}$.

plates; each well contained $1 \mathrm{ml}$ of medium, and the beads were added to a final concentration of 1500 beads/well. Corresponding cultures received equivalent concentrations of soluble rhGGF2, as based on the amount of rhGGF2 bound to the given beads (Table 1). All cultures were administered $\mathrm{BrdU}$ at a final concentration of $10 \mu \mathrm{M}$ at the time of bead addition.

Delivery of rhGGF2 to Schwann cells using coated beads resulted in unique responses. When cultured for $15 \mathrm{hr}$ in the presence of beads coated with $\geq 6 \mathrm{pg} \mathrm{rhGGF} / \mathrm{bead}$, a robust Schwann cell motility response was observed (Fig. 2). At lower concentrations, 0-3 pg rhGGF2/bead, Schwann cell behavior was unchanged. A concentration of $6 \mathrm{pg} / \mathrm{bead}$ elicited what appeared to be migration or movement of Schwann cells toward the beads: 5-10 cells/bead appear to have moved from the polystyrene culture substrate onto the coated beads (Fig. 2E). A more dramatic effect was observed at a concentration of $12 \mathrm{pg} / \mathrm{bead}$. In this case, the extent of movement toward the beads was increased, with the resultant formation of large aggregates of cells (two to three cell layers thick) and beads (Fig. $2 F$ ). Because rhGGF2 can elicit large aggregate formation in which not all participating cells seem to be
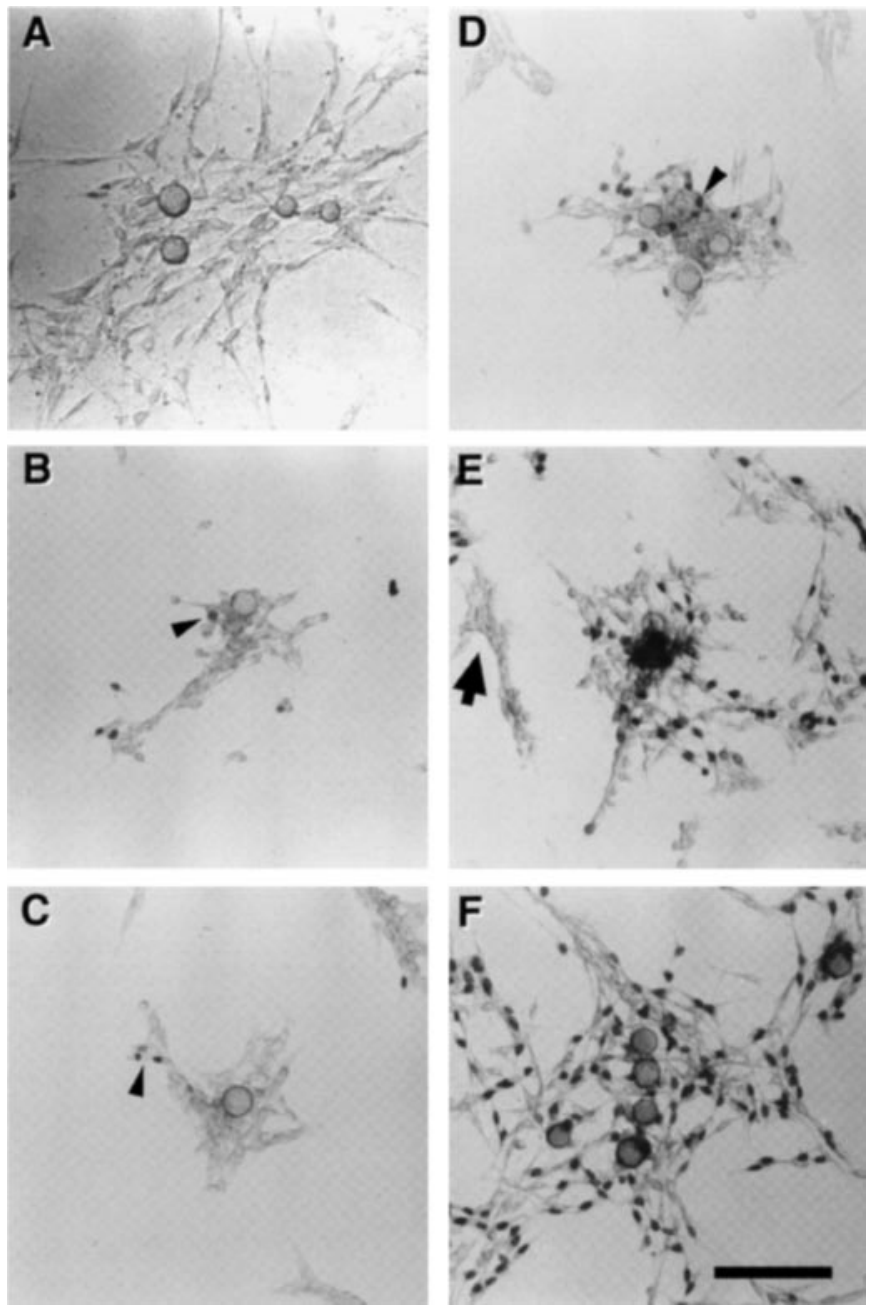

Figure 3. Beads coated with rhGGF2 promote Schwann cell DNA synthesis after $40 \mathrm{hr}$. Cultures were treated as in Figure 2 and were stained after $40 \mathrm{hr}$. Note the dose-dependent increase in BrdU-stained nuclei and that proliferating cells are localized to the beads. Arrowheads mark some of the few $\mathrm{BrdU}^{+}$cells in $B-D$. The large arrow in $E$ marks a Schwann cell cluster not associated with a bead and lacking BrdU staining. Concentrations of rhGGF2 (pg/bead): $(A) 0,(B) 0.75,(C) 1.5,(D) 3.0,(E) 6.0$, and (F) 12.0. Scale bar, $130 \mu \mathrm{m}$.

in direct contact with the beads, it is unlikely that the interactions were attributable merely to adhesion between coated beads and Schwann cells. In the case of the cells on the outside of such aggregates, however, electron microscopy will be necessary to rule out absolutely the possible contribution of cell contact with the beads via extremely thin processes. Nevertheless, aggregate formation cannot be attributed to highly localized proliferation because the cells were maintained in $10 \mu \mathrm{M}$ BrdU during the entire $15 \mathrm{hr}$ period, and little BrdU uptake was observed (cultures in Fig. 2 were immunostained for BrdU simultaneously with those shown in Figs. 3 and 4, the latter serving as a positive control). Thus when applied focally, rhGGF2 seems to elicit a clear chemotactic response in primary Schwann cells that is independent of mitotic activity.

Sister cultures maintained with the same beads for $40 \mathrm{hr}$ show a significant, dose-dependent proliferative response (Fig. 3). As in the case of the $15 \mathrm{hr}$ incubation, little response is observed at doses of $<6 \mathrm{pg}$ rhGGF2/bead. Beads coated solely with BSA cause little BrdU uptake (Fig. $3 A$ ), whereas at doses of 0.75-3.0 

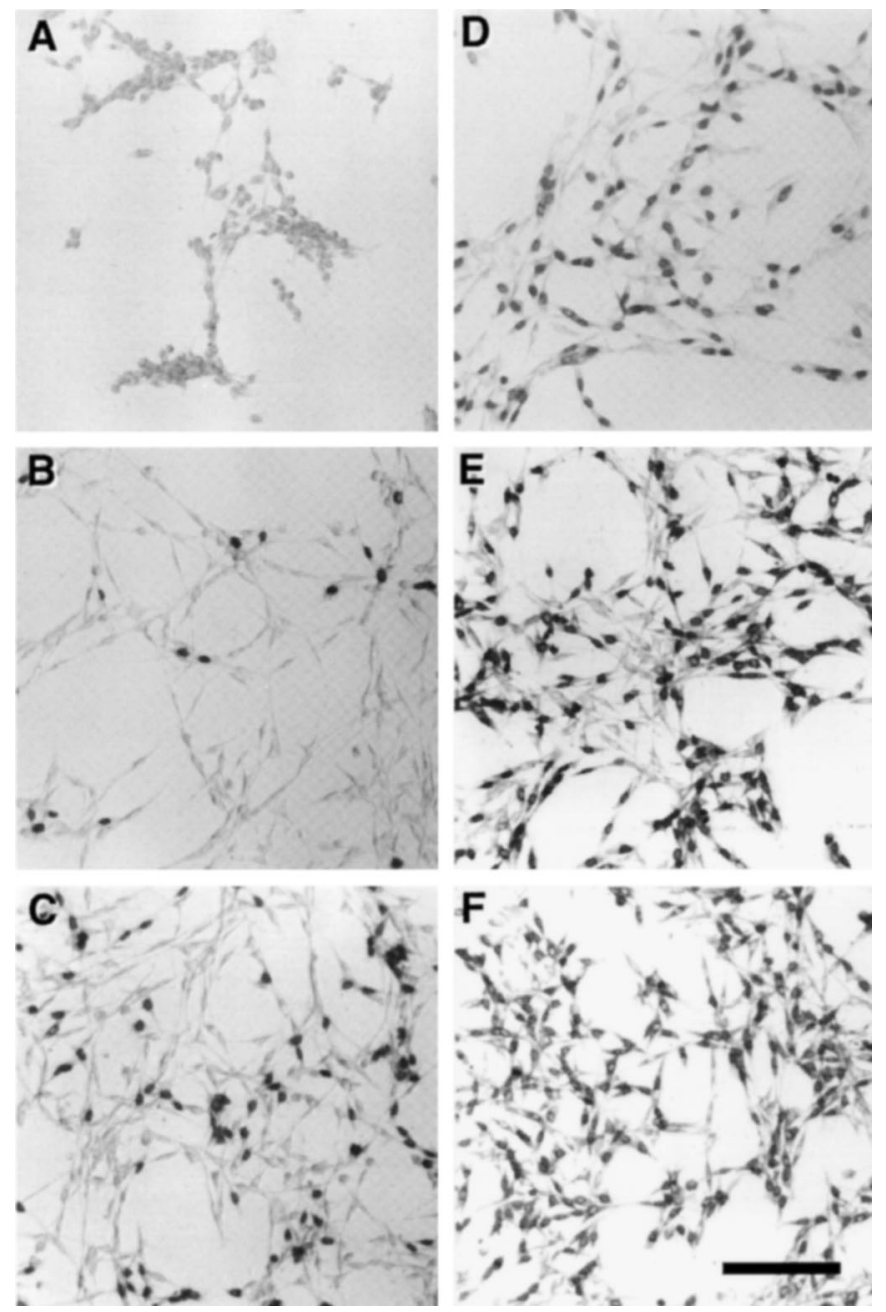

Figure 4. Soluble rhGGF2 promotes Schwann cell DNA synthesis without localization. In parallel with the cultures in Figures 1 and 2, equivalent concentrations of soluble rhGGF2 (see Table 1) were also tested, and the cultures were stained after $40 \mathrm{hr}$. Concentrations of rhGGF2 (ng/ml): $(A)$ 0, (B) 1.1, (C) 2.2, (D) 4.5, (E) 9.0, and $(F)$ 18.0. Scale bar, $130 \mu \mathrm{m}$.

pg, rhGGF2/bead occasional BrdU uptake can be seen (Fig. $3 B-D$ ). At a dose of $6 \mathrm{pg} / \mathrm{bead}, \mathrm{rhGGF} 2$ induces localized BrdU uptake; BrdU uptake is prominent within bead-associated islands of Schwann cells (Fig. $3 E$ ). Clusters of cells not in contact with a bead (Fig. 3E, large arrow) show no significant uptake. The highest dose tested, $12 \mathrm{pg} / \mathrm{bead}$, gave rise to a robust proliferative response that was not restricted to the immediate vicinity of the beads (Fig. $3 F$ ). Interestingly, in the cases of the 6 and $12 \mathrm{pg} / \mathrm{bead}$ treatments, by $40 \mathrm{hr}$ the Schwann cells appear to have disaggregated and returned to the polystyrene culture substrate when reentering the cell cycle (compare Figs. $2 E, F$ and $3 E, F$ ). It thus appears that the proliferative response of primary Schwann cells is a response subsequent to the chemotactic response observed at $15 \mathrm{hr}$.

In cultures that received soluble rhGGF2 at concentrations equivalent to their bead-treated counterparts, $40 \mathrm{hr}$ of rhGGF2 treatment induced dose-dependent proliferation of Schwann cells to a far greater extent than when tethered to beads, and this proliferation showed no localization (Fig. 4, Table 1). At earlier time points, cell clustering or aggregation akin to that in Figure $2 E, F$ was not observed. Thus focal administration of rhGGF2 reveals Schwann cell responses to the factor that are not obvious when the factor is administered uniformly.

\section{A novel explant culture system}

Entubulation is a common method of bridging experimentally created peripheral nerve gaps in vivo. By suturing the proximal and distal nerve stumps to opposite ends of a biocompatible tube (e.g., polyethylene), nerve regeneration can be facilitated, and the therapeutic value of various agents to this process can be evaluated by filling the tube with the agent of interest. To study this type of regeneration in vitro, a "tube culture" system was developed in which a portion of the SCG is placed at one end of a polyethylene tube filled with medium in a three-dimensional collagen matrix. This ganglion consists of both Schwann cells and a relatively homogeneous neuronal population that serves to mimic an entubulated proximal nerve stump. The tube provides an environment in which cellular "regrowth" is physically restricted to a geometry relevant to nerve regeneration in vivo and can be exposed to exogenous molecules of interest quite readily.

The semi-rigid matrix can be extruded from the tubes and entire cultures can be stained as "whole mounts" using antibodies against S-100 and tubulin $\beta$ III to mark Schwann cells (Fig. $5 A$ ) (Jessen and Mirsky, 1992) and axons (Fig. 5B) (Banerjee et al., 1990), respectively. The examples shown in Figure 5 were fixed and stained after $2 \mathrm{~d}$ in vitro, with the tube stained for S-100

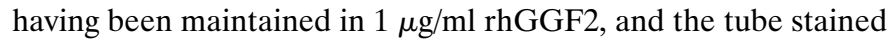
for tubulin $\beta$ III having been maintained in $10 \mathrm{ng} / \mathrm{ml} \mathrm{NGF}$. The outgrowth of both Schwann cells and neurites is highly directed within these cultures; although the lumen diameter of the tube greatly exceeds the size of the explanted ganglion, most outgrowth is preferentially oriented parallel to the long axis of the tube. It is possible that collagen induced to gel in this microenvironment forms an oriented matrix that may account for the directed outgrowth.

\section{Schwann cell outgrowth in the tube cultures increases in the presence of rhGGF2}

To examine the effects of rhGGF2 in an entubulation system, tube cultures were established in which the explants were exposed to 0 , 5,50 , and $500 \mathrm{ng} / \mathrm{ml} \mathrm{rhGGF2}$. At 2, 5, and $10 \mathrm{~d}$ of culture, tube cultures were extruded, fixed, and stained for S-100 and tubulin $\beta$ III. With use of a bright-field microscope equipped with a grid reticule, the number of Schwann cells within each $50 \mu \mathrm{m}$ interval (termed a "bin") from the explant was counted. For each condition at each time point, seven tubes were scored and the means plotted (Fig. 6). At $2 \mathrm{~d}$ in vitro, essentially no difference was observed between experimental groups in either the total number or the distribution of the Schwann cells appearing outside of the ganglion. By $5 \mathrm{~d}$, however, at all doses tested, rhGGF2 gave rise to a 2- to 2.5-fold increase in the total number of Schwann cells observed outside the explant. Furthermore, although the lowest dose of rhGGF2 tested in this assay saturated migration in the cryosection assay (compare Fig. 1), a modest dose-dependency in the extent of migration was observed. At 0, 5, 50, and $500 \mathrm{ng} / \mathrm{ml}$, the lead Schwann cells have traveled 0.95, 1.0, 1.1, and $1.3 \mathrm{~mm}$, respectively. A striking feature of this Schwann cell outgrowth is that it takes place in the absence of any detectable axonal outgrowth (see below). By $10 \mathrm{~d}$, the total cell number decreases relative to that observed at $5 \mathrm{~d}$; this could be attributable to nutrient depletion in the culture media (total volume per tube is $\sim 12 \mu \mathrm{l}$ ) and the onset of dehydration of the cultures. In addition, signs of dose-dependency in the observed migration have largely 

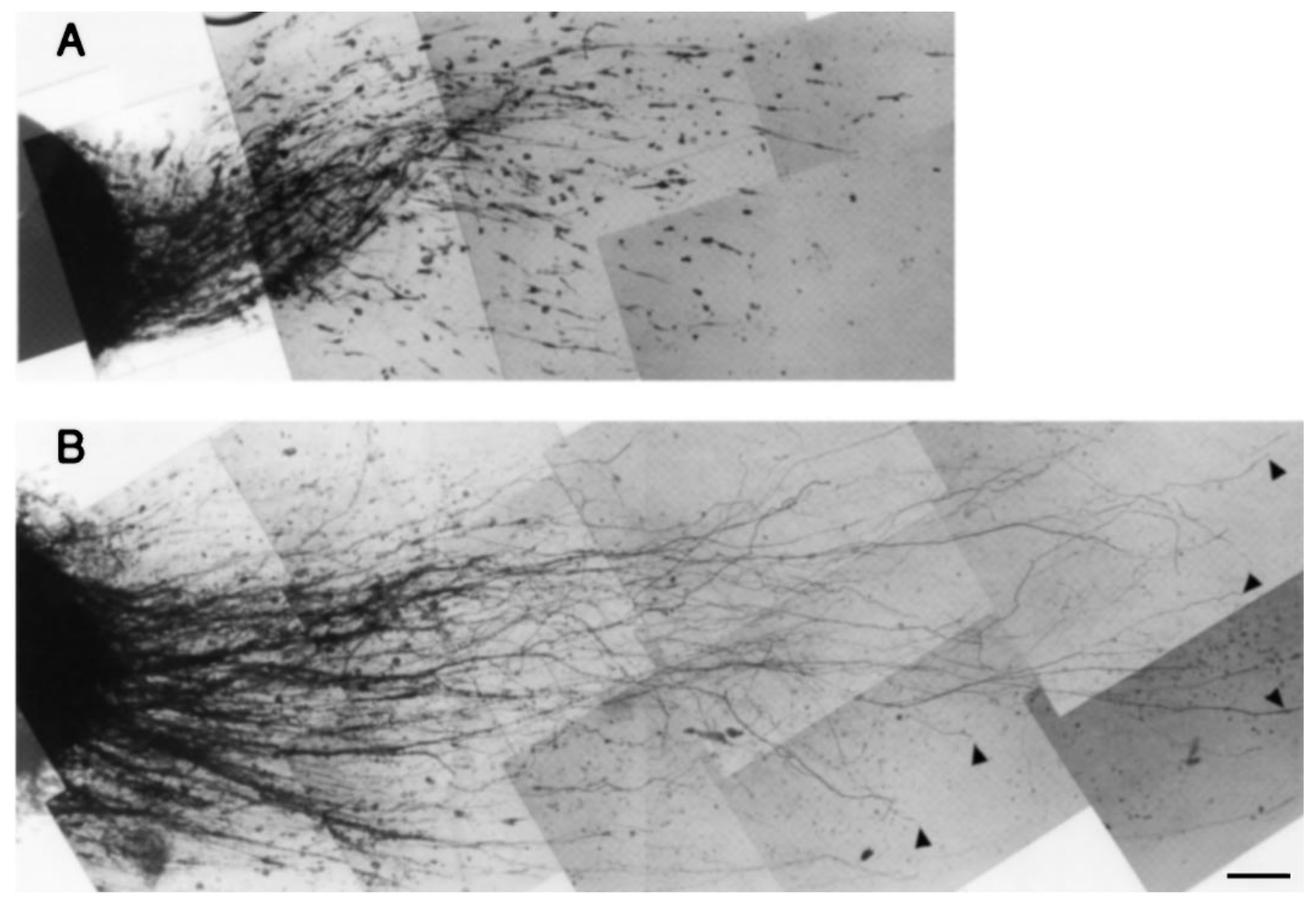

Figure 5. Schwann cell and neurite outgrowth in a novel explant culture system. Halves of SCGs were cultured in collagen gels within $10 \mathrm{~mm}$ lengths of 1.19-mm-diameter polyethylene tubing for $2 \mathrm{~d}$ in $1 \mu \mathrm{g} / \mathrm{ml} \mathrm{rhGGF2}(A)$ or $10 \mathrm{ng} / \mathrm{ml}$ NGF $(B)$. These cultures were stained for S-100 $(A)$ and tubulin $\beta$ III $(B)$ to mark Schwann cells and axons, respectively. Arrowheads in $B$ mark several of the many growth cones visible in such cultures. Scale bar, $100 \mu \mathrm{m}$.

vanished. Nevertheless, it can be seen that in all doses of rhGGF2 tested, Schwann cell number is greater than that of the control cultures, and the distance Schwann cells have moved from the explant in these conditions exceeds controls by $\sim 50 \%$ (an increase comparable to that observed in the cryosection-base assay; compare Fig. 1). Thus even in the absence of the complex cues provided by sciatic nerve cryosections, low doses of rhGGF2 promote outgrowth of Schwann cells from a peripheral ganglion, as measured by both cell number and distance traveled. The latter effect is a key observation, because an increase solely in cell number might be attributable to mitotic effects but would not explain an increase in the distance traveled.

\section{Initial Schwann cell outgrowth takes place in the absence of cell division}

To determine whether the increased cell number observed outside the explants was attributable to mitotic expansion of an intraganglionic population of Schwann cells, sister tube cultures were pulse-labeled with BrdU in one of two manners. In the first case, tubes were labeled for the $24 \mathrm{hr}$ period preceding extrusion to examine whether cells had undergone new DNA synthesis once outside the ganglion. In the second case, all tubes were labeled during day 1, and then removed from the labeling medium (see Materials and Methods for details), to examine the distribution of cells that were progeny of intraganglionic cell divisions.
In all rhGGF2-containing conditions, a large amount of label was observed within the explants (data not shown); because of the nature of the whole-mount analysis, quantification of this labeling was not possible. In both labeling protocols, no labeled cells were observed outside the explants at 2 and $5 \mathrm{~d}$ in vitro. At $10 \mathrm{~d}$, however, significant labeling was observed using both protocols (Fig. 7). When pulsed $24 \mathrm{hr}$ before fixation (Fig. 7, top), an increase in the number of labeled Schwann cells is observed within $300-350 \mu \mathrm{m}$ of the explant, with the number of dividing cells falling off rapidly beyond this distance. When pulsed on day 1 , progeny of early mitotic events are found in greater number, and this presumably reflects the multiple, intraganglionic mitotic events that took place between days 1 and 10 (Fig. 7, bottom).

In both labeling protocols, the number of labeled cells is greater in the presence of rhGGF2, but the distribution of labeled cells differs between the protocols. Although both protocols give rise to similar degrees of labeling distal to the explant, there are two- to threefold more labeled cells proximal to the explant when the cultures are labeled on day 1 than when labeled on day 10 . Thus the proximal population is likely to be attributable to an intraganglionic "population explosion" that pushes cells outward. The numbers of BrdU-labeled cells distal to the explants, however, are largely the same in both protocols. It is interesting to note that this labeling coincides with the appearance of neurites (see below). 

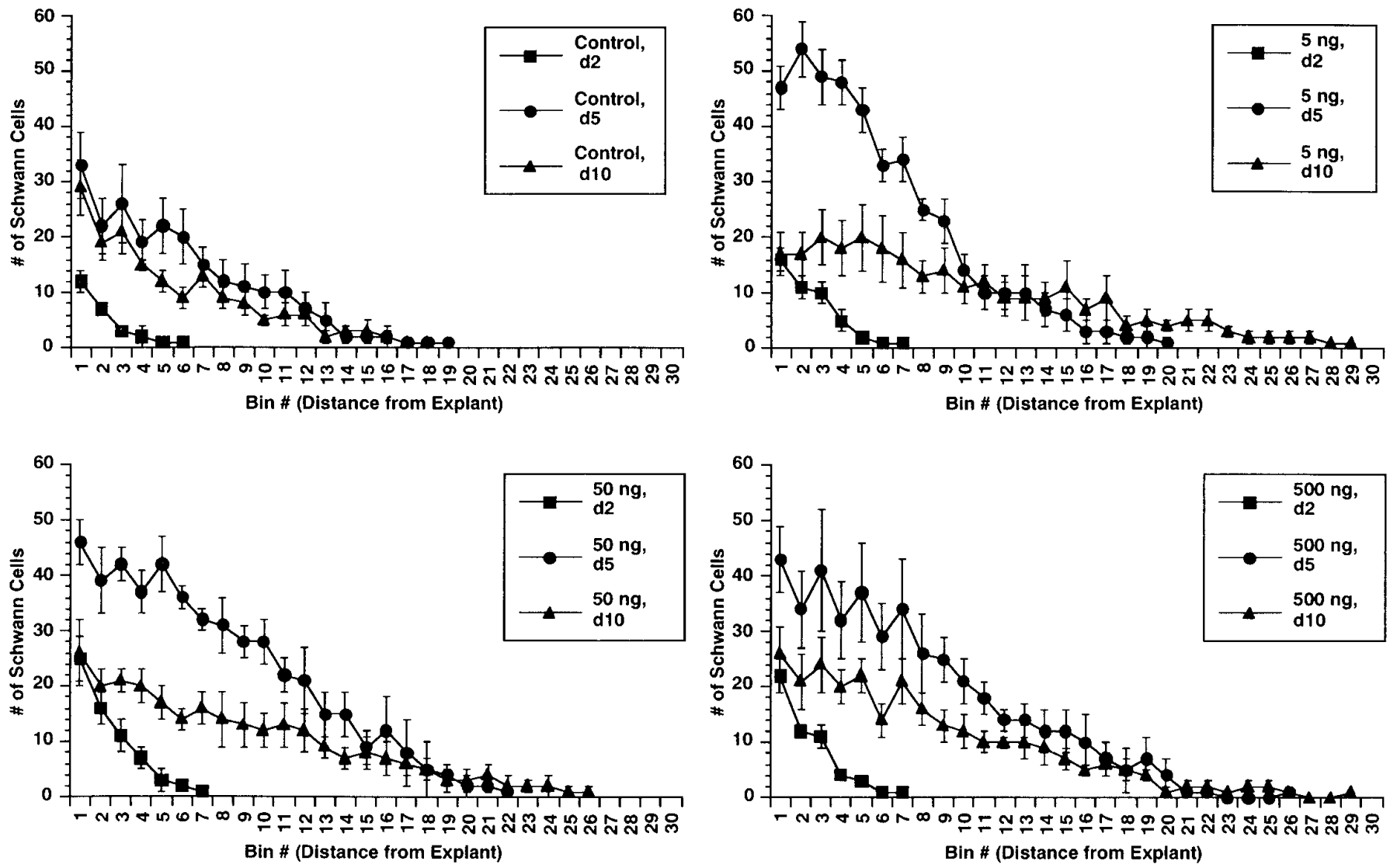

Figure 6. Schwann migration from ganglia increases in the presence of rhGGF2. Tube cultures similar to those in Figure 5 were maintained for 2, 5, and $10 \mathrm{~d}$ in the presence of 0 (control), 5, 50, and $500 \mathrm{ng} / \mathrm{ml} \mathrm{rhGGF2.} \mathrm{At} \mathrm{the} \mathrm{end} \mathrm{of} \mathrm{the} \mathrm{indicated} \mathrm{culture} \mathrm{period,} \mathrm{the} \mathrm{tubes} \mathrm{were} \mathrm{fixed} \mathrm{and} \mathrm{stained} \mathrm{for} \mathrm{S-100,}$ and the number of immunoreactive cells was scored at $50 \mu \mathrm{m}$ intervals (bins) from the explant. Data points represent the average \pm SEM; $n=6-7$.

Thus the labeling of the distal Schwann cell population could be in response to mitotic stimuli provided by the growing axons, or alternatively, migration is a saltatory phenomenon and the distal labeling corresponds to a "proliferative pause" that happens to occur at the time when neurites are first observed. Nevertheless, the Schwann cell outgrowth observed up through day 5 must be attributable to an rhGGF2-induced increase in Schwann cell motility that occurs in the absence of cell division.

\section{Neurite outgrowth in the tube cultures increases in the presence of rhGGF2}

Analysis of tubulin $\beta$ III staining in sister cultures revealed that no significant neurite outgrowth took place in these cultures until after $5 \mathrm{~d}$ in vitro. Thus all Schwann cell migration away from the SCG explants occurs independent of axon/Schwann cell interactions. At $10 \mathrm{~d}$ in vitro, however, significant neurite outgrowth was observed and displayed a distinctly different dose-dependency than that observed for Schwann cell outgrowth (Fig. 8). By $10 \mathrm{~d}$ in vitro, cultures maintained in $0-5 \mathrm{ng} / \mathrm{ml} \mathrm{rhGGF} 2$ showed similar levels of outgrowth. Using the same grid system with which Schwann cell number and distribution were scored, we found that the average number of neurite intersections fell from 10 to 15 at $50 \mu \mathrm{m}$ to a single neurite that terminated at $\sim 850 \mu \mathrm{m}$ from the explant. In the presence of 50 and $500 \mathrm{ng} / \mathrm{ml} \mathrm{rhGGF2,} \mathrm{however,}$ 30-40 neurite intersections were observed at $50 \mu \mathrm{m}$, and the number fell to 0 at only $1.1-1.2 \mathrm{~mm}$ from the explant. At the distance at which the longest neurite terminated in the 0 and 5 $\mathrm{ng} / \mathrm{ml}$ conditions, there were 10 -fold more neurites in the 50 and
$500 \mathrm{ng} / \mathrm{ml}$ conditions. Thus, although the lowest dose of rhGGF2 tested, $5 \mathrm{ng} / \mathrm{ml}$, seems to saturate the Schwann cell outgrowth response, higher doses are required to promote neurite outgrowth from the SCG.

\section{The effects of rhGGF2 on neurite outgrowth are mediated by Schwann cells}

Two different mechanisms can account for the different rhGGF2 dose-response profiles of Schwann cell proliferation and neurite outgrowth. In the first, Schwann cells and neurons respond to rhGGF2 differently because of the use of different receptors or receptor complexes. In the second, Schwann cells migrate and proliferate in response to low doses of rhGGF2 and produce neurite-promoting factors in response to high doses of rhGGF2. To test the first hypothesis, low density, dissociated SCG neuron cultures, depleted of non-neuronal cells, were simultaneously exposed to varying doses of both rhGGF2 and NGF. As can be seen in Figure 9 (top), rhGGF2 neither promotes SCG neuron survival nor shifts NGF dose-responsiveness. There was no obvious effect of rhGGF2 on neurite outgrowth in this $48 \mathrm{hr}$ assay. Thus it is unlikely that the effects of rhGGF2 on neurite outgrowth are direct.

To examine whether the effects on neurite outgrowth were mediated indirectly, Schwann cells were plated at two initial plating densities $\left(1 \times 10^{5}\right.$ and $5 \times 10^{5}$ cells/well in 24-well plates $)$ in $0,5,50$, and $500 \mathrm{ng} / \mathrm{ml} \mathrm{rhGGF} 2$, and the conditioned media were harvested after $5 \mathrm{~d}$. As expected, Schwann cell numbers increased with increasing rhGGF2 concentration but were not 

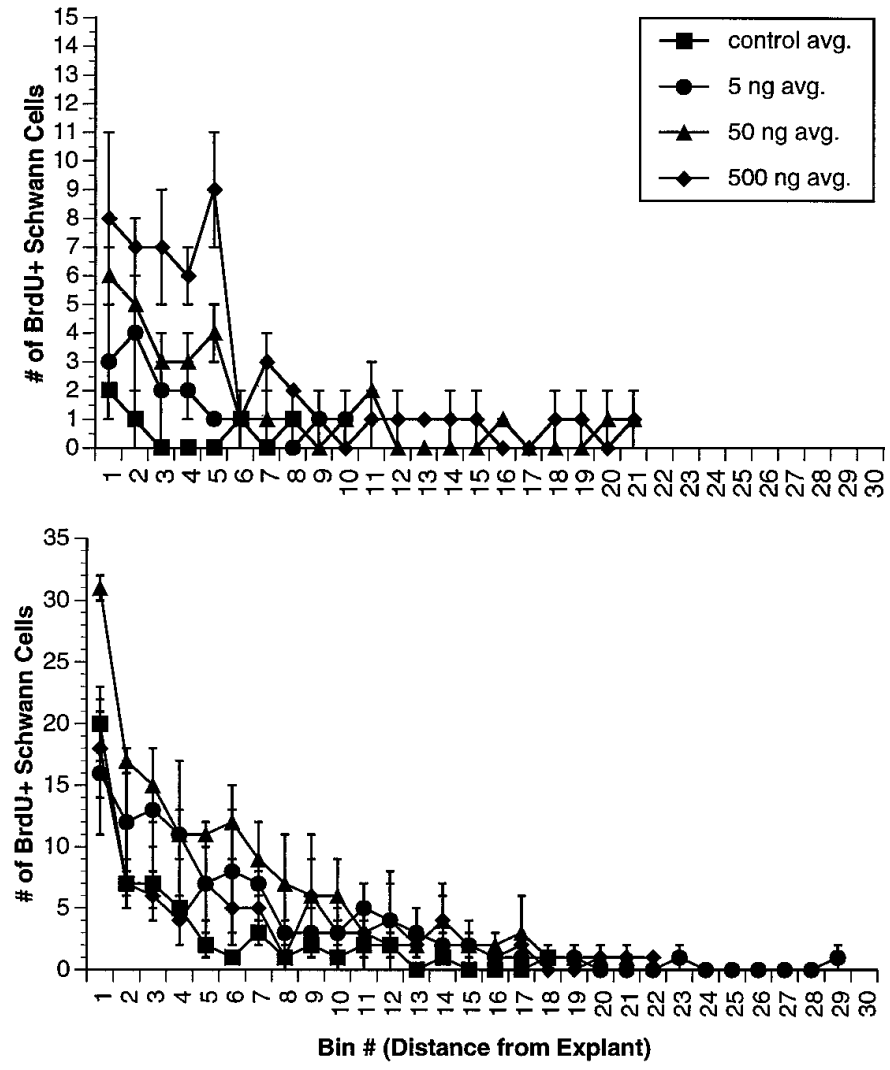

Figure 7. Extraganglionic DNA synthesis commences after $5 \mathrm{~d}$ in vitro. Tube cultures similar to those in Figure 5 were maintained for $10 \mathrm{~d}$ in the

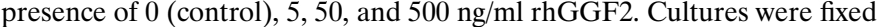
and stained for BrdU, and the number of immunoreactive cells was scored at $50 \mu \mathrm{m}$ intervals (bins) from the explant. Data points represent the average \pm SEM; $n=3$. Cultures were pulsed with BrdU for $24 \mathrm{hr}$ on either day 9 (top) or day 1 (bottom).

significantly different between the two higher doses. To "normalize" the amount of secreted activity in the conditioned media, cell counts were made at the time of harvest, and the media were diluted by a factor proportional to the number of Schwann cells

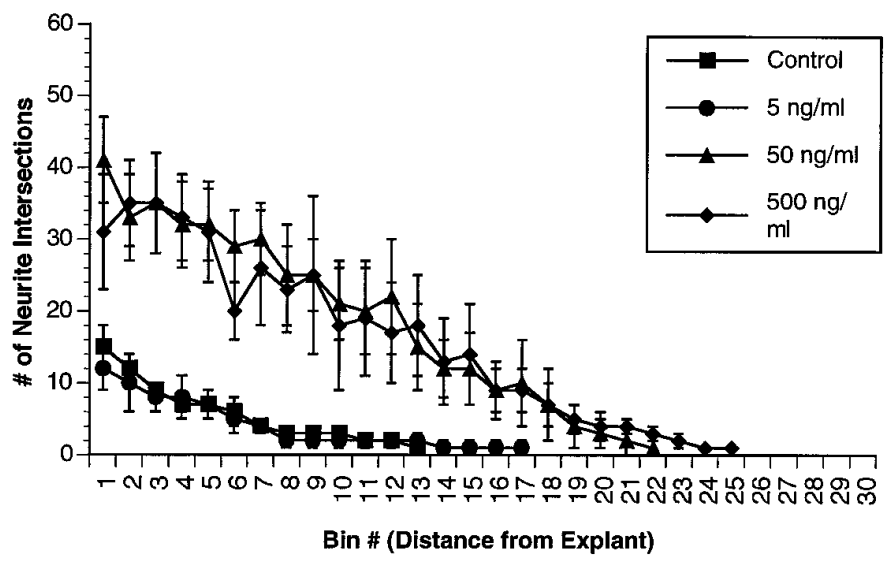

Figure 8. Ganglionic neurite outgrowth is promoted by rhGGF2. Tube cultures similar to those in Figure 5 were maintained for $10 \mathrm{~d}$ in the

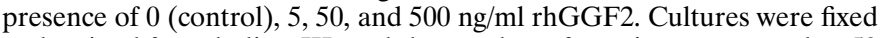
and stained for tubulin $\beta \mathrm{III}$, and the number of neurites was scored at 50 $\mu \mathrm{m}$ intervals (bins) from the explant (noted as "intersections" with the scoring grid). Data points represent the average \pm SEM; $n=6-7$. present in the corresponding control cultures. This manipulation assured that increases in secreted activity could be attributed to increases in the amount of activity secreted per cell rather than to the mere increase in total Schwann cell number. Low density, dissociated SCG neuron cultures were established in these conditioned media, and as can be seen in Figure 9 (bottom), rhGGF2 induces the production of neurotrophic activity by Schwann cells in a dose-dependent manner. This is most apparent when the medium-conditioning Schwann cells are plated at high density. In the case of Schwann cells plated at $5 \times 10^{5} /$ well in the presence of $500 \mathrm{ng} / \mathrm{ml} \mathrm{rhGGF2}$, secreted activity gives rise to a fourfold increase in neuron survival. All surviving neurons show comparable levels of neurite outgrowth. Although these experiments do not rule out the possibility that SCG neurons respond to rhGGF2 directly when in the presence of Schwann cells or factors secreted by Schwann cells, they clearly demonstrate that in the absence of exogenous NGF, the ability of Schwann cells to promote neuron survival and outgrowth by way of secreted activities is greatly increased by rhGGF2.

\section{DISCUSSION}

\section{Neuregulin-induced Schwann cell migration}

Here we demonstrate, by using three distinct in vitro assay systems, that rhGGF2 is a Schwann cell chemoattractant. In two paradigms, "global" administration of rhGGF2 to organotypic populations of Schwann cells (i.e., DRG or SCG explants) promoted migration of Schwann cells on cryosections of peripheral nerve or through a type I collagen matrix. In another paradigm, using purified Schwann cells, rhGGF2-coated beads caused focal accumulation of cells in a dose-dependent manner. In all three cases, the increased motility occurred in the absence of DNA synthesis. Proliferation did occur in these experiments, but only after a delay that varied with culture system. In the case of the pure Schwann cell cultures, DNA synthesis was observed after 48 hr of rhGGF2 application; this agrees with previous studies in which rhGGF2 was administered to purified Schwann cells in monolayer culture (Rutkowski et al., 1995). In the organotypic systems, significant extraganglionic DNA synthesis did not take place until at least $5 \mathrm{~d}$ of culture. In both cases, however, increased motility and proliferation were temporally distinct events. The cryosection paradigm (Fig. 1) demonstrates that rhGGF2 maximally increases Schwann cell motility at doses that are submaximal for promoting mitosis, whereas the coated-bead paradigm demonstrates that such motility can be directed and hence can be viewed as chemotactic.

\section{Neuregulin-induced Schwann cell proliferation}

The disparate delays in the onset of Schwann cell proliferation between the assay systems in our studies seems to be a function of the presence or absence of neurons in the cultures. In the absence of neurons, beads are capable of inducing proliferation over an expected time course when coated with sufficient rhGGF2. In tubes, however, the simultaneous presence of neurons seems to modify the responsiveness of Schwann cells to rhGGF2 such that the migratory response is protracted and the onset of extraganglionic proliferation correlates with the appearance of outgrowing neurites. In the case of the tube cultures, the observed proliferation is likely to be attributable to a combination of neuregulins exogenous and endogenous to the cultures (Salzer et al., 1980a,b; Morrissey et al., 1994) as well as other neuronal factors that give rise to a proliferative response different from that of isolated Schwann cells. 

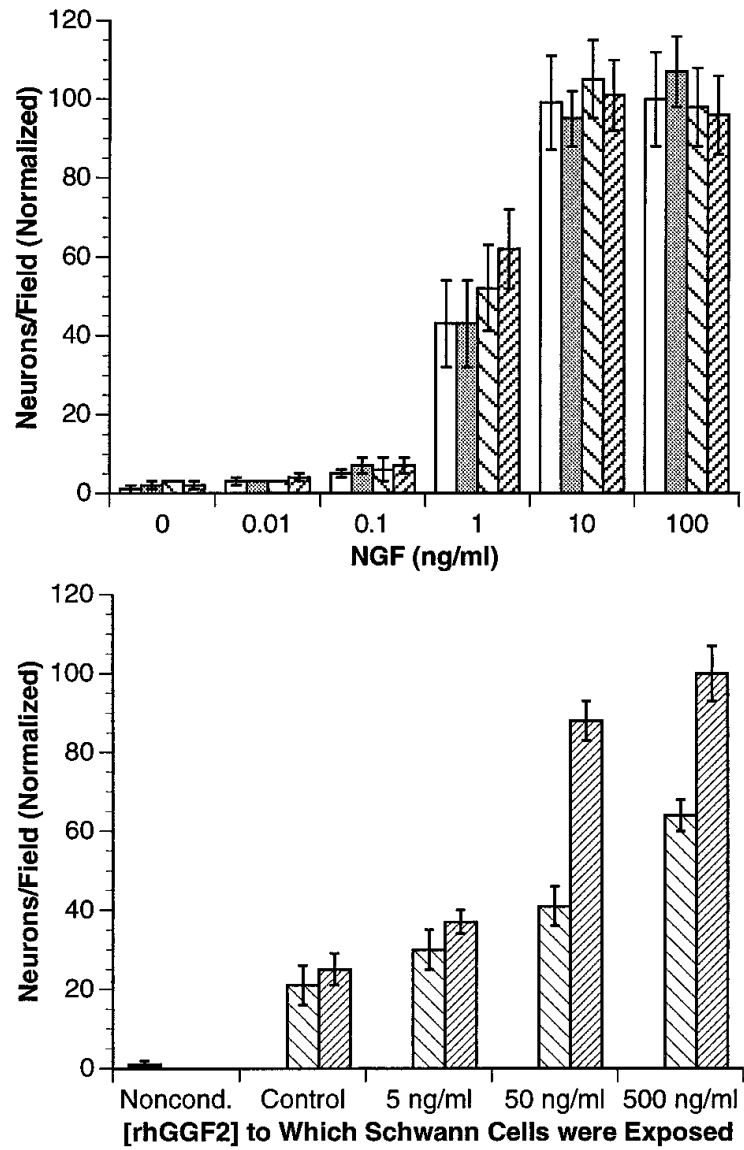

Figure 9. Neurotrophic factors are produced by Schwann cells in response to rhGGF2. Top, Dissociated SCG neurons were cultured in the indicated concentrations of rhGGF2 and NGF, and the number of tubulin $\beta \mathrm{III}^{+}$neurons was scored after $48 \mathrm{hr}$. No direct effect of rhGGF2 on SCG neuron survival was observed. Bars represent the average \pm $\mathrm{SEM} ; n=20$ fields scored from four independent cultures. Bottom, Similar SCG neuron cultures were established in media conditioned for $5 \mathrm{~d}$ by Schwann cells plated at two different densities and treated with the indicated concentrations of rhGGF2 (control = no rhGGF2). Before neurons were plated in conditioned media, all media were diluted by a factor proportional to cell number in the Schwann cell cultures at the time of medium collection (for details, see Results). The number of tubulin $\beta \mathrm{III}^{+}$neurons was scored after $48 \mathrm{hr}$. Schwann cells produce increasing trophic activity in response to increasing rhGGF2 concentration. Bars represent the average $\pm \mathrm{SEM} ; n=10$.

\section{Neuregulin induction of neurotrophic support}

The tube cultures demonstrated that rhGGF2 promotes neurite outgrowth and that this effect is pronounced at doses greater than necessary to stimulate migration and proliferation. This was unlikely to be a direct effect, because outgrowth took 5-10 d to manifest and was more consistent with accumulation of neuritepromoting or neurotrophic activities in the tubes. To rule out direct rhGGF2 effects, dissociated SCG neurons were cultured in the presence of varying doses of both rhGGF2 and NGF. As shown in Figure 9 (top), rhGGF2 neither promoted neuron survival nor modulated NGF dependency. To examine whether rhGGF2 promoted neuron survival or outgrowth via Schwann cells, conditioned media were collected from rhGGF2-treated Schwann cell cultures. Because rhGGF2 treatment results in Schwann cell proliferation, conditioned media were diluted in proportion to cell number at the time of harvest. This manipulation served to normalize the concentration of constitutive secretions that could affect neuronal behavior (i.e., dilution in this manner unmasks increased production of neuroactive substances on a per cell basis). Figure 9 (bottom) shows that rhGGF2 does promote the production of Schwann cell-derived activities trophic for SCG neurons.

It is important to note that in the assays presented in Figure 9, the extent of neurite outgrowth was not appreciably different among the surviving neurons. Thus the increases in neurite outgrowth observed in the tube cultures (Fig. 8) are likely to be attributable to the tropic effect that can be exerted by trophic factors (Gunderson and Barrett, 1980). Furthermore, the 5-10 d lag period for the appearance of neurites is likely to be accounted for by the accumulation of Schwann cell secretions rather than any refractory period for neurite extension in this culture system. This is made clear by the observation that massive neurite outgrowth can be observed at $2 \mathrm{~d}$ in vitro in the presence of exogenous NGF (Fig. 5B).

Schwann cells are capable of producing various factors that support neuron survival and outgrowth (for a comprehensive review, see Scherer and Salzer, 1996). Factors secreted by Schwann cells that can affect neuronal survival include NGF, brain-derived neurotrophic factor (Meyer et al., 1992), leukemia inhibitory factor (Curtis et al., 1994), and ciliary neurotrophic factor (Friedman et al., 1992). Extracellular matrix proteins such as laminin and fibronectin (Reichardt and Tomaselli, 1991), as well as proteases and protease inhibitors (Patterson, 1985), promote neurite outgrowth and are also secreted by Schwann cells. Although this study did not set out to identify the specific factors released by Schwann cells in response to rhGGF2, the functional assay using SCG neurons makes a strong case that NGF or neurotrophin-3 or both are the critically upregulated factors (ElShamy et al., 1996). Additional studies will be necessary to characterize the full profile of upregulated protein expression, and it will be important for such studies to make use of Schwann cells treated with supramitotic doses of neuregulins.

\section{Neuregulins and peripheral nerve regeneration}

Studies of samples derived in vivo have demonstrated that factors promoting Schwann cell migration and proliferation accumulate in the fluid surrounding regenerating peripheral nerve (LeBeau et al., 1988). In addition, regenerating axons demonstrate clear tropism toward Schwann cells residing in degenerated nerves (Ramon y Cajal, 1928; Politis et al., 1982; Kuffler, 1986). Could 
neuregulins be mediators of both events? Neuronal secretion of neuregulins could certainly account for the observed migration and proliferation of Schwann cells. Furthermore, given that neurotrophic factors can be tropic factors for peripheral neurons (Gunderson and Barrett, 1980), neuregulin-induced production of neurotrophic factors by Schwann cells would promote the emission of tropic signals.

Of the three neuregulin receptor subunits, expression of erbB2 has been examined most closely in developing peripheral nerve. In the peripheral nervous system, erbB2 expression is confined to the Schwann cell lineage, peaks on postnatal day 1, and is coincident with the peak of mitotic activity (Jin et al., 1993). Although normal expression decreases rapidly during the first two postnatal weeks, erbB2 expression is strikingly upregulated by nerve transection (Cohen et al., 1992). If neuregulins secreted by regenerating neurons establish a concentration gradient, highest at the neuronal growth cones and decreasing toward the periphery, the renewed sensitivity of distal Schwann cells upregulating erbB2 could allow differential signaling as a function of distance. In such a scenario, Schwann cells at a distance would be recruited to the injury site by low concentrations of neuregulins (chemotaxis), begin to proliferate as they entered the mitotic concentration zone, and then act as local sources of trophic support when exposed to supramitotic concentrations near the regenerating axons. Indeed, Schwann cells seem to migrate out of transected distal nerve stumps both in vivo and in vitro (Ramon y Cajal, 1928; Martini et al., 1990). Alternatively, because neuregulins are also produced as membrane-spanning isoforms (for review, see Mudge, 1993; Peles and Yarden, 1993), soluble neuregulins may promote chemotaxis, whereas axonal forms may induce both proliferation and growth factor production. In the culture systems presented here, high concentrations of the rhGGF2 might mimic the effects of membrane-spanning isoforms. Nevertheless, in either model, regenerating axons could "bootstrap" along cordons of Schwann cells in degenerated nerves to previous targets of innervation. Thus it seems that a reciprocating interaction between neurons and Schwann cells may be key to successful peripheral nerve regeneration, and one component of this reciprocity is neuron-derived neuregulin.

\section{REFERENCES}

Anton ES, Weskamp G, Reichardt LF, Matthew WD (1994) Nerve growth factor and its low affinity receptor promote Schwann cell migration. Proc Natl Acad Sci USA 91:2795-2799.

Banerjee A, Roach MC, Trcka P, Luduena RF (1990) Increased microtubule assembly in bovine brain tubulin lacking the type III isotype of $\beta$-tubulin. J Biol Chem 1990:1794-1799.

Brockes JP (1987) Assay and isolation of glial growth factor from the bovine pituitary. Methods Enzymol 147:217-225.

Carraway KL, Burden SJ (1995) Neuregulins and their receptors. Curr Biol 5:1-7.

Chen MS, Bermingham-McDonogh O, Danehy FT, Nolan C, Scherer SS, Lucas J, Gwynne D, Marchionni MA (1994) Expression of multiple neuregulin transcripts in postnatal rat brains. J Comp Neurol 349:389-400.

Cohen JA, Yachnis AT, Arai M, Davis JG, Scherer SS (1992) Expression of the neu proto-oncogene by Schwann cells during peripheral nerve development and Wallerian degeneration. J Neurosci Res 31:622-634.

Curtis R, Scherer SS, Somogyi R, Adryan KM, Ip NY, Zhu Y, Lindsay RM, DiStefano PS (1994) Retrograde axonal transport of LIF is increased by peripheral nerve injury: correlation with increased LIF expression in the distal nerve. Neuron 12:191-204.

Dong Z, Brennan A, Liu N, Yarden Y, Lefkowitz G, Mirsky R, Jessen KR (1995) Neu differentiation factor is a neuron-glia signal and regulates survival, proliferation, and maturation of rat Schwann cell precursors. Neuron 15:585-596.
ElShamy WM, Linnarsson S, Lee K-F, Jaenisch R, Ernfors P (1996) Prenatal and postnatal requirements of NT-3 for sympathetic neuroblast survival and innervation of specific targets. Development 122:491-500.

Falls DL, Rosen KM, Corfas G, Lane WS, Fischbach GD (1993) ARIA, a protein that stimulates acetylcholine receptor synthesis, is a member of the neu ligand family. Cell 72:801-815.

Friedman B, Scherer SS, Rudge JS, Helgren M, Morrisey D, McClain J, Wang D, Furth ME, Lindsay RM, Ip NY (1992) Regulation of ciliary neurotrophic factor expression in myelin-related Schwann cells in vivo. Neuron 9:295-305.

Gassmann M, Casagranda F, Orioli D, Simon H, Lai C, Klein R, Lemke G (1995) Aberrant neural and cardiac development in mice lacking the ErbB4 neuregulin receptor. Nature 378:390-394.

Goodearl ADJ, Davis JB, Mistry K, Minghetti L, Otsu M, Waterfield MD, Stroobant P (1993) Purification of multiple forms of glial growth factor. J Biol Chem 268:18095-18102.

Gunderson RW, Barrett JN (1980) Characterization of the turning response of dorsal root neurites toward nerve growth factor. J Cell Biol 87:546-554.

Holmes WE, Slikowski MX, Akita RW, Henzel WJ, Lee J, Park JW, Yansura D, Abadi N, Raab H, Lewis GD, Shepard HM, Kuang W-J, Wood WI, Goeddel DV (1992) Identification of heregulin, a specific activator of $\mathrm{p} 185^{\mathrm{erbB} 2}$. Science 256:1205-1210.

Jessen KR, Mirsky R (1992) Schwann cells: early lineage, regulation of proliferation and control of myelin formation. Curr Opin Neurobiol 2:575-581.

Jin JJ, Nikitin AY, Rajewsky MF (1993) Schwann cell lineage-specific neu (erbB-2) gene expression in the developing rat nervous system. Cell Growth Differ 4:227-237.

Kuffler DP (1986) Isolated satellite cells of a peripheral nerve direct the growth of regenerating frog axons. J Comp Neurol 249:57-64.

LeBeau JM, LaCorbiere M, Powell HC, Ellisman MH, Schubert D (1988) Extracellular fluid conditioned during peripheral nerve regeneration stimulates Schwann cell adhesion, migration, and proliferation. Brain Res 459:93-104.

Lee K-F, Simon H, Chen H, Bates B, Hung M-C, Hauser C (1995) Requirement for neuregulin receptor erbB2 in neural and cardiac development. Nature 378:394-398.

Lemke GE, Brockes JP (1984) Identification and purification of glial growth factor. J Neurosci 4:75-83.

Marchionni MA, Goodearl ADJ, Chen MS, Bermingham-McDonogh O, Kirk C, Henricks M, Danehy F, Misumi D, Sudhalter J, Kobayashi K, Wroblewski D, Lynch C, Baldassare M, Hiles I, Davis JB, Hsuan JJ, Totty NF, Otsu M, McBurney RN, Waterfield MD, Stroobant P, Gwynne D (1993) Glial growth factors are alternatively spliced erbB2 ligands expressed in the nervous system. Nature 362:312-318.

Martini R, Schachner M, Faissner A (1990) Enhanced expression of the extracellular matrix molecule $\mathrm{J} 1 /$ tenascin in the regenerating adult mouse sciatic nerve. J Neurocytol 19:601-616.

Meyer D, Birchmeier C (1994) Distinct isoforms of neuregulin are expressed in mesenchymal and neuronal cells during mouse development. Proc Natl Acad Sci USA 91:1064-1068.

Meyer D, Birchmeier C (1995) Multiple essential functions of neuregulin in development. Nature 378:386-390.

Meyer M, Matsuoka I, Wetmore C, Olson L, Thoenen H (1992) Enhanced synthesis of brain-derived neurotrophic factor in the lesioned peripheral nerve: different mechanisms are responsible for the regulation of BDNF and NGF mRNA. J Cell Biol 119:45-54.

Morrissey TK, Levi ADO, Sliwkowski MX, Bunge RP (1994) Heregulin and $\mathrm{p} 185^{\mathrm{erbB} 2}$ are involved in axon-induced Schwann cell proliferation. Soc Neurosci Abstr 20:707.

Mudge AW (1993) New ligands for Neu? Curr Biol 3:361-364.

Orr-Urtreger A, Trakhtenbrot L, Ben-Levy R, Wen D, Rechavi G, Lonai P, Yarden Y (1993) Neural expression and chromosomal mapping of Neu differentiation factor to $8 \mathrm{p} 12-\mathrm{p} 21$. Proc Natl Acad Sci USA 90:1867-1871.

Patterson PH (1985) On the role of proteases, their inhibitors, and the extracellular matrix in promoting neurite outgrowth. J Physiol (Paris) 80:207-211.

Peles E, Yarden Y (1993) Neu and its ligands: from an oncogene to neural factors. Bioessays 15:815-824.

Politis MJ, Ederle K, Spencer PS (1982) Tropism in nerve regeneration in vivo. Attraction of regenerating axons by diffusible factors derived 
from cells in distal nerve stumps of transected peripheral nerves. Brain Res 253:1-12.

Ramon y Cajal S (1928) Degeneration and regeneration of the nervous system. Oxford: Oxford UP.

Reichardt LF, Tomaselli KJ (1991) Extracellular matrix molecules and their receptors: functions in neural development. Annu Rev Neurosci 14:531-570.

Rutkowski JL, Kirk CJ, Lerner MA, Tennekoon GI (1995) Purification and expression of human Schwann cells in vitro. Nature Med 1:80-83.

Salzer JL, Bunge RP, Glaser L (1980a) Studies of Schwann cell proliferation. III. Evidence for the surface localization of then neurite mitogen. J Cell Biol 84:767-778.

Salzer JL, Williams AK, Glaser L, Bunge RP (1980b) Studies of Schwann cell proliferation. II. Characterization of the stimulation and specificity of the response to a neurite membrane fraction. J Cell Biol 84:753-766.

Scherer SS, Salzer JL (1996) Axon-Schwann cell interactions during pe- ripheral nerve degeneration and regeneration. In: Glial cell development: basic principles and clinical relevance (Jessen KR, Richardson WD, eds). Oxford: Bios Scientific.

Shah NM, Marchionni MA, Issacs I, Stoobant P, Anderson DJ (1994) Glial growth factor restricts mammalian neural crest stem cells to a glial fate. Cell 77:349-360.

Sudhalter J, Whitehouse L, Rusche JR, Marchionni MA, Mahanthappa NK (1996) Schwann cell heparan sulfate proteoglycans play a critical role in glial growth factor/neuregulin signaling. Glia 17:28-38.

Trachtenberg JT, Thompson WJ (1996) Schwann cell apoptosis at developing neuromuscular junctions is regulated by glial growth factor. Nature 379:174-177.

Wen D, Peles E, Cupples R, Suggs SV, Bacus SS, Luo Y, Trail G, Hu S, Silberger SM, Ben-Levy R, Koski RA, Lu HS, Yarden Y (1992) Neu differentiation factor: a transmembrane glycoprotein containing an EGF domain and an immunoglobulin homology unit. Cell 69:559-572. 